OPEN ACCESS

Edited by:

Ruiwen Zhang,

University of Houston, United States

Reviewed by:

Esther Del Olmo,

University of Salamanca, Spain

Didem Sohretoglu,

Hacettepe University, Turkey

*Correspondence:

Song Gao

gsong@yzu.edu.cn

Specialty section:

This article was submitted to

Ethnopharmacology,

a section of the journal

Frontiers in Pharmacology

Received: 15 March 2021

Accepted: 24 June 2021

Published: 06 July 2021

Citation:

Huan C, Xu Y, Zhang W, Guo T, Pan H and Gao $S$ (2021) Research Progress on the Antiviral Activity of Glycyrrhizin and its Derivatives in Liquorice. Front. Pharmacol. 12:680674. doi: 10.3389/fphar.2021.680674

\section{Research Progress on the Antiviral Activity of Glycyrrhizin and its Derivatives in Liquorice}

\author{
Changchao Huan ${ }^{1,2,3}$, Yao Xu ${ }^{1,2,3}$, Wei Zhang ${ }^{1,2,3}$, Tingting Guo ${ }^{4}$, Haochun Pan $^{1,2,3}$ and \\ Song $\mathrm{Gao}^{1,2,3 *}$
}

${ }^{1}$ Institutes of Agricultural Science and Technology Development, College of Veterinary Medicine, Yangzhou University, Yangzhou, China, ${ }^{2}$ Jiangsu Co-Innovation Center for Prevention and Control of Important Animal Infectious Diseases and Zoonoses, Yangzhou, China, ${ }^{3}$ Key Laboratory of Avian Bioproduct Development, Ministry of Agriculture and Rural Affairs, Yangzhou, China, ${ }^{4}$ College of Medicine, Yangzhou University, Yangzhou, China

Liquorice is a traditional medicine. Triterpenoids such as glycyrrhizin and glycyrrhetinic acid are the main active constituents of liquorice. Studies have revealed that these compounds exert inhibitory effects on several viruses, including SARS-CoV-2. The main mechanisms of action of these compounds include inhibition of virus replication, direct inactivation of viruses, inhibition of inflammation mediated by HMGB1/TLR4, inhibition of $\beta$-chemokines, reduction in the binding of HMGB1 to DNA to weaken the activity of viruses, and inhibition of reactive oxygen species formation. We herein review the research progress on the antiviral effects of glycyrrhizin and its derivatives. In addition, we emphasise the significance of exploring unknown antiviral mechanisms, structural modifications, and drug combinations in future studies.

Keywords: liquorice, triterpenoid, antiviral activity, glycyrrhizin, glycyrrhetinic acid

\section{INTRODUCTION}

Liquorice has been documented as a herbal medicine in ancient medical books of China, India, and Greece and has been used for thousands of years (Zeng et al., 1988). Primarily, it is used in clinics to treat diseases of the respiratory, digestive, and immune systems (Deng et al., 2017; Sun et al., 2018; Yan et al., 2018; Yao and Sun, 2019; Paudel et al., 2020; Yang et al., 2020). Liquorice has favourable preventive and therapeutic effects on various diseases, with fewer side effects (Kwon et al., 2020); therefore, research and mining of potential pharmacological activities of liquorice have been a hot topic in the field of pharmacology. Currently, many experimental results have shown that liquorice and its extract have antibacterial, antiviral, anti-inflammatory, anticancer, antioxidant, liver protection, neuroprotection, skin whitening, hypoglycaemic, memory-enhancing, and other biological activities (Petramfar et al., 2020), indicating that liquorice holds a great developmental and application prospect in cosmetic production and in the treatment of liver diseases, diabetes, ischaemia-reperfusion injury, Alzheimer's disease, Parkinson's disease, epilepsy, depression, and cancer (Pastorino et al., 2018; Li et al., 2019; Zhang et al., 2021).

Glycyrrhizin (also known as glycyrrhizic acid or glycyrrhizinic acid) (Drugs B.I., 2006) and glycyrrhetinic acid, which are the most important chemical constituents of liquorice, belong to the class triterpenoids. Among all saponins in liquorice, glycyrrhizin is present in the highest amount (>2\%), and its content in wild, high-quality liquorice can be as high as 7\% (Zhang and Ye, 2009). Glycyrrhizin is metabolised through the gastrointestinal tract to produce glycyrrhetinic acid (Figure 1) (Yang, 2020), which also possesses many pharmacological properties, and its most 


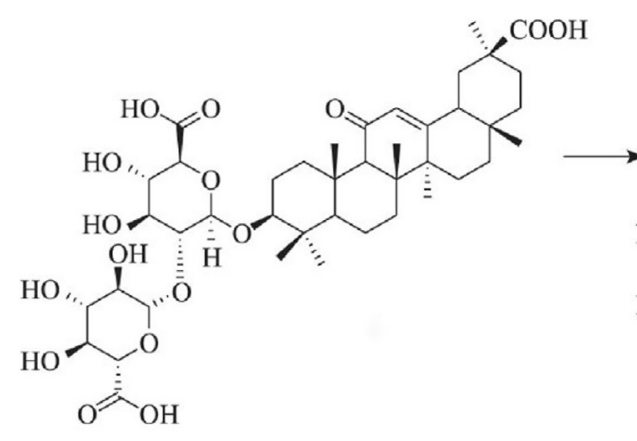

Glycyrrhizin

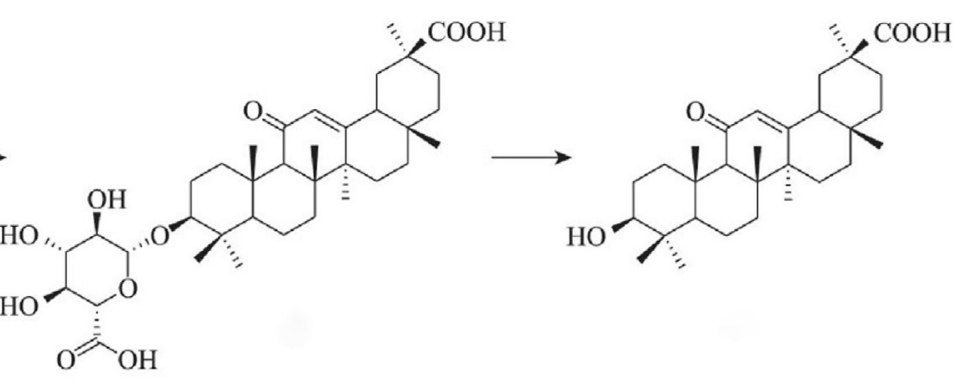

Glycyrrhetinic acid

FIGURE 1 | The structure and metabolic relationship between glycyrrhizin and glycyrrhetinic acid.

interesting property is its antiviral activity. Glycyrrhizin exerts inhibitory effects on hepatitis C virus (HCV) (Zhang et al., 2020), herpes simplex type 1 (HSV-1) (Hirabayashi et al., 1991), influenza virus (Wolkerstorfer et al., 2009), and severe acute respiratory syndrome (SARS)-associated coronaviruses (Cinatl et al., 2003). This article reviews the research progress on the antiviral activity of glycyrrhizin and its derivatives in liquorice to provide a reference for further scientific research and for guiding clinical applications. Although only a few reports are available on the role of glycyrrhizin in herpes virus and human immunodeficiency virus (HIV) infections, we present information about herpes virus and HIV based on studies by Pu et al. (2013) and Huan et al. (2020), and these aspects form the basis of the present review. Overall, our review discusses advances in research on the antiviral properties and mechanism of action of glycyrrhizin.

\section{ANTI-HERPES VIRUS ACTIVITY}

Herpes virus is one of the most common viruses infecting animals and humans. More than $90 \%$ adults have been infected with at least one or more types of herpes viruses, and the viruses usually establish a latent infection (Chayavichitsilp et al., 2009). Some herpes viruses lead to lifelong infections, which are common worldwide (Bradley et al., 2014; Okonko and Cookey, 2015; Reward et al., 2019).

In 1979, a study reported that glycyrrhizic acid could directly inactivate HSV [multiplicities of infection $(\mathrm{MOI})=5$ ], and this effect was found to be irreversible (Pompei et al., 1979). Subsequently, some researchers detected the anti-HSV effects of glycyrrhetinic acid derivatives, sodium carbenoxolone sodium (CBX), and cicloxolone sodium (CCX) (Dargan and SubakSharpe, 1986). Through in vivo and in vitro studies, researchers found that $500 \mu \mathrm{M} \mathrm{CBX}$ and $300 \mu \mathrm{M}$ CCX have anti-HSV-1 and anti-HSV-2 (MOI = 5) activities, and thus can significantly inhibit virus replication and reduce the number of infectious virus particles by $10,000-100,000$ times.
Glycyrrhizin inhibits HSV-1 replication in vitro, and its $\mathrm{IC}_{50}$ is $0.5 \mathrm{mM}$ (Hirabayashi et al., 1991). Sekizawa et al. (2001) revealed that glycyrrhizin could increase the survival rate of HSV-1infected mice. Ikeda et al. (2005) found that glycyrrhizin and glycyrrhetic acid inhibited HSV-1 replication, and the effect of glycyrrhetic acid was 10 times greater than that of glycyrrhizin. Glycyrrhizin was also shown to reduce adhesion between cerebral capillary vessel endothelial cells and polymorphonuclear leukocytes in the treatment of HSV infection (Huang et al., 2012).

Curreli et al. (2005) found that latent infection with kaposi sarcoma-associated herpesvirus (KSHV) in B lymphocytes could be terminated using glycyrrhizic acid. Glycyrrhizic acid was found to block the latent KSHV infection by upregulating the expression of viral cyclin (ORF72) and downregulating the expression of latency-associated nuclear antigen (LANA), thereby selectively inducing death of KSHV-infected cells. Glycyrrhizic acid was also reported to inhibit KSHV replication in patients with hepatitits $B$ virus (HBV) infection (Xie et al., 2011). In addition, Kang and Lieberman (2011) found that glycyrrhizic acid decreases transcription during KSHV latency to inhibit virus replication. They confirmed that glycyrrhizic acid disrupts the RNA polymerase II (RNAPII) complex and alters the enrichment of the RNAPII-pausing complex. Furthermore, glycyrrhizic acid was shown to reduce the interaction between SMC3 and RAD21 and between SPT5 and RNAPII. Moreover, it abrogatated RNAPII to pause at intragenic CTCF-cohesion binding sites, leading to reduced mRNA production and a defect in sister chromatid cohesion.

Lin (2003) proved that glycyrrhizic acid dose-dependently inhibits the Epstein-Barr virus (EBV) replication. Glycyrrhizic acid mainly plays an antiviral role in the early stage of the EBV replication cycle; however, it does not affect the adsorption and inactivation of virus particles. Lin et al. (2008) found that seven derivatives of glycyrrhizic acid could inhibit EBV infection in a dose-dependent manner, and the antiviral activity of these derivatives was enhanced when amino acid residues were introduced into the carbohydrate part of glycyrrhizic acid. The authors also reported that $18 \beta$-glycyrrhetinic acid (the metabolic 
product of glycyrrhizic acid) is 7.5-fold more active against EBV than glycyrrhizic acid (Lin et al., 2008).

Cellular SUMOylation processes are the proposed targets for antiviral therapies. Bentz et al. (2019) found that glycyrrhizic acid inhibits SUMOylation processes, limits cell growth, and induces apoptosis in multiple cell lines. Glycyrrhizic acid acts on the first step of the SUMOylation process and leads to low levels of spontaneous EBV reactivation. Glycyrrhizic acid was not found to affect the induced reactivation of the virus; however, its extract was shown to reduce the ability of the virus to infect the remaining cells (Lin et al., 2008). Therefore, glycyrrhizic acid may be beneficial in the treatment of EBV-related malignant tumours and other diseases caused by the SUMOylation process.

\section{ANTI-HEPATITIS VIRUS ACTIVITY}

Glycyrrhizic acid exhibits direct anti-hepatitis virus activity and low toxicity in host cells (Romero et al., 2005). It has been used to treat chronic hepatitis for many years in Japan. Glycyrrhizin can inhibit the secretion of HBV surface antigen (HBsAg) in PLC/ $\mathrm{PRF} / 5$ cells in vitro, which leads to its accumulation in the cytoplasmic vacuoles of the Golgi apparatus, changes in the intracellular transport of HBsAg, and inhibition of its sialylation in a dose-dependent manner (Takahara et al., 1994). Sato et al. (1996) revealed that glycyrrhizin could bind to hepatocytes at a certain concentration, change the expression of HBV-related antigens on hepatocytes, and inhibit the sialylation of HBsAg. Matsuo et al. (2001) revealed that glycyrrhizin in combination with lamivudine may inhibit HBV replication in an HBV carrier with non-Hodgkin lymphoma.

Glycyrrhizin can not only effectively inhibit HBV infection but also exhibit a strong anti-HCV activity. Ashfaq et al. (2011) used a nontoxic dose of glycyrrhizin to detect its antiviral activity in $\mathrm{HCV}$-infected hepatocytes. The study results revealed that glycyrrhizin can decrease the titre of hepatitis $\mathrm{C}$ virus $\left(2 \times 10^{5}\right.$ copies of $\mathrm{HCV}$ infection) by $50 \%$ at a concentration of $7 \pm 1 \mu \mathrm{g} /$ $\mathrm{ml}$. Additionally, its inhibitory effect increased when it was used in combination with interferon. In addition to interferon (Fujisawa, 1991), glycyrrhizin is used in combination with various drugs to treat hepatitis virus infection, and its use in combination with other drugs has yielded superior clinical outcomes (Tandon et al., 2001; Tarao, 2001; Hidaka et al., 2007; Chen et al., 2017). A glycyrrhizin-containing preparation, Stronger Neo-Minophagen $C^{\mathrm{TM}}$ (SNMC), protects mitochondria by reducing oxidative stress during HCV treatment in transgenic mice (Korenaga et al., 2011). Matsumoto et al. (2013) demonstrated that glycyrrhizin can decrease the release of infectious HCV particles by inhibiting PLA2G1B.

A recent study reported that glycyrrhetinic acid could inhibit the release of high-mobility group box 1 (HMGB1), block the cytokine activity of HMGB1, and significantly improve the liver inflammatory injury induced by mouse hepatitis virus $(1 \times$ $10^{4} \mathrm{PFU} / \mathrm{mouse}$ ) through the HMGB1-TLR4 signalling pathway. This protective effect is related to a substantial reduction in IL-17 and IL-22 levels rather than the direct inhibition of intracellular virus replication (Shi et al., 2020).

\section{ANTI-INFLUENZA VIRUS ACTIVITY}

The effect of glycyrrhizic acid on influenza virus was reported in the early 1980s. In vitro experiments by Pompei et al. (1983) demonstrated that glycyrrhizic acid could inhibit the replication of influenza virus in chicken embryos by reducing the haemagglutinin level. The mechanism of inhibition of influenza virus replication by glycyrrhizic acid has been reported (Wolkerstorfer et al., 2009; Michaelis et al., 2010; Sakai-Sugino et al., 2017). A combination of HMGB1 with influenza virus nucleoprotein can promote the growth of influenza virus and enhance the activity of virus polymerase (Moisy et al., 2012). Glycyrrhizin can reduce the activity of influenza virus polymerase by antagonising this binding effect, thus inhibiting influenza virus replication (Paudel et al., 2020). Michaelis et al. (2011) found that $200 \mu \mathrm{g} / \mathrm{ml}$ glycyrrhizin could significantly reduce the cytopathic effect (CPE) caused by $\mathrm{H} 5 \mathrm{~N} 1$ influenza virus infection at an MOI of $0.01,0.1$, or 1 in A549 cells. The therapeutic concentration of glycyrrhizin interferes with the replication of highly pathogenic $\mathrm{H} 5 \mathrm{~N} 1$ influenza A virus at least partly by interfering with the formation of reactive oxygen species (ROS) induced by $\mathrm{H} 5 \mathrm{~N} 1$, thereby reducing the activation of $\mathrm{p} 38$, JNK, and NF-kB in lung cells. Glycyrrhizin was also found to inhibit H5N1-induced production of CXCL10, IL-6, and CCL5 $(\mathrm{MOI}=2)$ and $\mathrm{H} 5 \mathrm{~N} 1$-induced apoptosis without affecting virus replication and NK cell activity (Michaelis et al., 2010).

The combination of glycyrrhizic acid with various drugs produces a synergistic effect, which protects against influenza virus infection. Smirnov et al. (2012) studied the regulatory effects of glutamyl-tryptophan (EW) and glycyrrhizic acid and their combination on influenza A (H3N2) virus infection in mice (1 or $\left.10 \mathrm{LD}_{50}\right)$. The results revealed that compared with EW alone, glycyrrhizic acid (10 mg/kg body weight) in combination with EW $(0.1 \mu \mathrm{g} / \mathrm{kg}, 10 \mu \mathrm{g} / \mathrm{kg}$, and $1,000 \mu \mathrm{g} / \mathrm{kg})$ produced significant antiviral effects, which alleviated lung oedema and inflammatory cell infiltration. Use of glycyrrhizic acid in combination with ribavirin, a broad-spectrum antiviral drug, significantly inhibited lung consolidation in mice infected with $\mathrm{H} 1 \mathrm{~N} 1$ influenza virus. A combination of $50 \mathrm{mg} \mathrm{kg-}{ }^{1} \mathrm{~d}-{ }^{1}$ glycyrrhizin and $40 \mathrm{mg} \mathrm{kg}-^{1} \mathrm{~d}-{ }^{1}$ ribavirin was found to provide $100 \%$ protection to infected mice (5 times LD50 of influenza $\mathrm{H} 1 \mathrm{~N} 1$ virus infection), suggesting that the combination of ribavirin and glycyrrhizin has a potential clinical value (Chen et al., 2015b).

\section{ANTI-HUMAN IMMUNODEFICIENCY VIRUS ACTIVITY}

Studies have shown that glycyrrhizin inhibits HIV replication in a dose-dependent manner (Ito et al., 1987; Ito et al., 1988; Hattori et al., 1989). Ito et al. (1988) found that glycyrrhizin at a concentration of $0.6 \mathrm{mM}$ completely inhibited HIV-induced $(\mathrm{MOI}=0.002)$ MT-4 cell plaque formation as well as HIVinduced cytopathogenicity in MT-4 and MOLT-4 cells in vitro (Hirabayashi et al., 1991).

In addition, glycyrrhizin increases the number of OKT4 lymphocytes and improves liver dysfunction and thus prevents 
the progression of haemophilia to AIDS in HIV-positive patients with haemophilia (Mori et al., 1989). Glycyrrhizin can not only inhibit HIV replication but also affect the entry of HIV into cells. HIV requires chemokine receptors or chemokine receptor-like molecules to enter cells (Cocchi et al., 1996; Feng et al., 2011). Sasaki et al. (2002) found that glycyrrhizin could induce the production of CC chemokine ligand (CCL) 4 and CCL5 in cultures of peripheral blood mononuclear cells from HIVinfected patients. These $\beta$-chemokines can compete with HIV to bind with chemokine receptors, thus inhibiting the entry of NSI-HIV. CC chemokine receptor 5 (CCR5) or CXC-chemokine receptor 4 (CXCR4) are the coreceptors necessary for HIV-1 entry into cells (Alkhatib et al., 1996; Dragic et al., 1996). Yoshida et al. (2009) and Takei et al. (2005) confirmed that glycyrrhizin can greatly inhibit the production of CCL2 and interleukin 10 (IL-10). Consequently, CCR5 expression, which is mediated by CCL2 or IL-10, reduces significantly, resulting in effective inhibition of the entry of HIV into cells.

Glycyrrhizin can also reduce the fluidity of the cell membrane, which reduces intercellular fusion, thus inhibiting the spread of HIV across cells. Harada (2005) washed the cells treated with glycyrrhizin, added the replacement medium lacking glycyrrhizin, and observed a time-dependent increase in the fluidity of the membrane as well as in the sensitivity of the cells to infection and fusion. This finding provides a novel strategy for the prevention and treatment of enveloped viruses.

\section{ANTI- SARS-COV ACTIVITY}

Researchers began investigating the role of glycyrrhizin in protection against SARS-associated coronavirus (SARS-CoV) infection after the outbreak of SARS in 2003. Cinatl et al. (2003) evaluated the antiviral effects of five drugs, including ribavirin and glycyrrhizin, on SARS-CoV, and glycyrrhizin was found to exhibit the strongest inhibitory effect on SARS-CoV replication in Vero cells. Furthermore, a study found that glycyrrhizin can inhibit the early stages of the virus replication cycle, namely adsorption and penetration, and the effect of glycyrrhizin addition on virus adsorption was not found to be as good as that of glycyrrhizin addition after virus adsorption. However, Chen et al. (2004) could not detect the inhibitory effect of glycyrrhizin on SARS-CoV in the fRhK-4 cell line. The modification of the glycyrrhizin structure, particularly the production of amide derivatives and amino acid conjugates, can significantly improve its anti-SARS-CoV activity, although this modification increases its cytotoxicity (Hoever et al., 2005). In clinical trials, clinical symptoms such as dyspnoea improved rapidly (Lu et al., 2003), the average time for lung lesion improvement from the most severe to $50 \%$ decreased, and no side effects were observed in the glycyrrhizin treatment group (Wu et al., 2004).

SARS-CoV-2 is a novel coronavirus, and the coronavirus disease 2019 pandemic caused by SARS-CoV-2 was named coronavirus disease-2019 (COVID-2019) by the World Health Organisation (WHO) (Coronaviridae Study Group of the International Committee on Taxonomy of, 2020; Li et al.,
2020; Zhu et al., 2020). SARS-CoV-2 and SARS-CoV gene sequences share $79.5 \%$ homology (Zhou et al., 2020), and many similarities have been observed in the clinical symptoms of the infections caused by these two viruses (Wang et al., 2020). Therefore, whether glycyrrhizin shows antiviral activity against SARS-CoV-2 similar to SARS-CoV remains to be investigated (Bailly and Vergoten, 2020). Luo et al. (2020) explored the potential pharmacological effects of glycyrrhizin in COVID-19 treatment. The authors found that glycyrrhizin exerts various pharmacological effects such as angiotensin-converting enzyme II (ACE2) binding, proinflammatory cytokine downregulation, endogenous interferon induction, inhibition of intracellular $\mathrm{R}$ accumulation and thrombin, and excessive production of airway exudates. These findings suggest that glycyrrhizin may be a promising drug for COVID-19 treatment (Ding et al., 2020; Murck, 2020; Chrzanowski et al., 2021).

In a recent study, glycyrrhizin significantly inhibited SARSCoV-2 (MOI $=0.01)$ replication in Vero E6 cells in a dosedependent manner and exhibited no significant cytotoxicity (Gowda et al., 2021). Glycyrrhizin can also prevent virus replication (100 $\mathrm{TCID}_{50}$ of SARS-CoV-2) by inhibiting the viral main protease $\mathrm{M}^{\text {pro }}$ (Sinha et al., 2021; van de Sand et al., 2021). Using computer-aided drug design and biological verification, Yu et al. (2021) found that glycyrrhizin is the most effective and nontoxic broad-spectrum anti-coronavirus molecule in vitro, particularly against SARS-CoV-2.

\section{EFFECTS ON SOME ANIMAL VIRUSES}

Glycyrrhizin has demonstrated antiviral activity against some animal viruses. Li et al. (2009) studied the effect of glycyrrhizin diammonium on infectious bronchitis virus $(\mathrm{IBV})$ cell infection $(\mathrm{MOI}=0.001)$ through CPE observation, plaque reduction test, and RT-PCR. The results revealed that glycyrrhizin diammonium has a direct antiviral activity and that it can completely inhibit cell infection. Glycyrrhizin alone or in combination with duck hepatitis virus (DHV) vaccine has demonstrated good immune stimulant and antiviral effects against DHV (Soufy et al., 2012; Okda et al., 2013). Dipotassium glycyrrhizinate can directly inactivate and/or interfere with infectious bursal disease virus (IBDV) replication and effectively inhibit IBDV infection $\left(100 \mathrm{TCID}_{50}, 1 \times 10^{-1.5}\right)$ in vitro (Sun et al., 2013). Li et al. (2014) found that diammonium glycyrrhizinate (DG) exerts an antiviral effect on porcine testicular (ST) cells infected with PPV (100 TCID 50 ), and DG was found to have a strong inhibitory effect on PPV when the virus was treated before incubation. DG also demonstrated its antiviral activity against Marc- 145 cells infected with porcine reproductive and respiratory syndrome virus (PRRSV). PRRSV could be effectively controlled through inhibition of viral replication and $\mathrm{N}$ gene expression and through reduction of apoptosis (Wang et al., 2013). Studies have also reported that glycyrrhizin mainly inhibits the penetration of PRRSV and has a slight effect on the adsorption or release of PRRSV during its life cycle (Duan et al., 2015). By using carbon dots (CDs) with high biocompatibility and glycyrrhizic acid, Tong et al. (2020) synthesised Gly-CDs through the hydrothermal method. These GlyCDs could inhibit the invasion and replication of PRRSV, stimulate the 
TABLE 1 | The antiviral activity and mechanism of actions of glycyrrhizin and its derivatives.

\begin{tabular}{|c|c|c|c|c|}
\hline Virus & & Mechanisms of action & $\begin{array}{l}\text { Glycyrrhizin and its } \\
\text { derivatives }\end{array}$ & References \\
\hline \multirow{4}{*}{$\begin{array}{l}\text { Herpes } \\
\text { virus }\end{array}$} & HSV-1 & Directly inactivates herpes simplex virus & Glycyrrhizic acid (8 mM) & Pompei et al. (1979) \\
\hline & $\begin{array}{l}\text { HSV-1, } \\
\text { HSV-2 }\end{array}$ & Inhibition of virus replication & $\begin{array}{l}\text { Carbenoxolone sodium }(500 \mu \mathrm{M}) \text { and cicloxolone } \\
\text { sodium }(300 \mu \mathrm{M})\end{array}$ & $\begin{array}{l}\text { Dargan and } \\
\text { Subak-Sharpe, (1986) }\end{array}$ \\
\hline & KSHV & $\begin{array}{l}\text { Upregulation of the expression of viral cyclin and } \\
\text { downregulation of the expression of latency-associated } \\
\text { nuclear antigen, selectively inducing cell death in KSHV- } \\
\text { infected cells }\end{array}$ & Glycyrrhizic acid (3 mM, 4 mM) & Curreli et al. (2005) \\
\hline & EBV & $\begin{array}{l}\text { Inhibit virus invasion into host cells in the early stages of } \\
\text { virus replication; inhibit the sumerization process, } \\
\text { prevent cell proliferation, increase cell death, and } \\
\text { prevent the resulting virus from infecting new cells }\end{array}$ & $\begin{array}{l}\text { Glycyrrhizic acid }\left(\mathrm{IC}_{50}=0.04 \mathrm{mM}\right) \text {; glycyrrhizic acid }(0.5 \\
1.0,2.0,3.0,4.0 \mathrm{mM})\end{array}$ & $\begin{array}{l}\text { (Lin, 2003; Bentz et al., } \\
\text { 2019) }\end{array}$ \\
\hline \multirow[t]{3}{*}{$\begin{array}{l}\text { Hepatitis } \\
\text { virus }\end{array}$} & HBV & $\begin{array}{l}\text { Inhibition of hepatitis B surface antigen secretion, } \\
\text { sialylation, and intracellular transpo }\end{array}$ & Glycyrrhizin (0.5mg/ml, 1 mg/ml, 2 mg/ml) & Takahara et al. (1994) \\
\hline & $\mathrm{HCV}$ & $\begin{array}{l}\text { Inhibition of HCV3a core gene expression at mRNA and } \\
\text { protein levels }\end{array}$ & Glycyrrhizin $(2.5 \mu \mathrm{g} / \mathrm{ml}, 5 \mu \mathrm{g} / \mathrm{ml}, 10 \mu \mathrm{g} / \mathrm{ml}, 20 \mu \mathrm{g} / \mathrm{ml})$ & Ashfaq et al. (2011) \\
\hline & $\begin{array}{l}\text { Mouse } \\
\text { hepatitis virus }\end{array}$ & $\begin{array}{l}\text { Improvement of liver inflammatory injury through the } \\
\text { high-mobility group box } 1 \text { (HMGB1)-TLR4 signal } \\
\text { pathway }\end{array}$ & 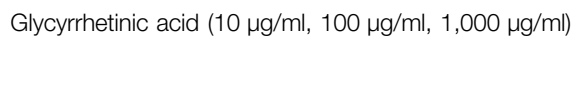 & Shi et al. (2020) \\
\hline \multirow[t]{3}{*}{$\begin{array}{l}\text { Influenza } \\
\text { virus }\end{array}$} & $\mathrm{H} 5 \mathrm{~N} 1$ & $\begin{array}{l}\text { Inhibits the formation of ROS induced by } \mathrm{H} 5 \mathrm{~N} 1 \text { and then } \\
\text { decreases the activation of } \mathrm{NF \kappa B}, \mathrm{JNK} \text {, and p38 }\end{array}$ & 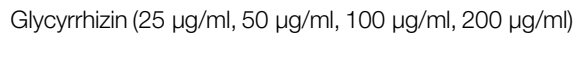 & Michaelis et al. (2011) \\
\hline & Influenza virus & $\begin{array}{l}\text { Antagonises the binding of HMGB1 to influenza virus } \\
\text { nucleoprotein and reduces the activity of influenza virus } \\
\text { polymerase, thus inhibiting the replication of influenza } \\
\text { virus }\end{array}$ & Glycyrrhizin & Moisy et al. (2012) \\
\hline & $\mathrm{H} 5 \mathrm{~N} 1$ & $\begin{array}{l}\text { Inhibits H5N1-induced CXCL10, IL-6 and CCL5 } \\
\text { production, inhibits H5N1-induced apoptosis but does } \\
\text { not interfere with H5N1 replication }\end{array}$ & 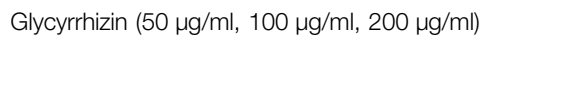 & Michaelis et al. (2010) \\
\hline \multirow[t]{3}{*}{ HIV } & HIV-1 & Inhibition of virus replication by inhibiting protein kinase $\mathrm{C}$ & Glycyrrhizin $(0.075,0.15,0.3,0.6,1.2,2.4 \mathrm{mM})$ & Ito et al. (1988) \\
\hline & NSI-HIV & $\begin{array}{l}\text { Inhibition of NSI-HIV replication in PBMC by inducing the } \\
\text { production of } \beta \text {-chemokines (CCL } 4 \text { and CCL5) }\end{array}$ & Glycyrrhizin $(0.1 \mu \mathrm{g} / \mathrm{ml}, 1 \mu \mathrm{g} / \mathrm{ml}, 10 \mu \mathrm{g} / \mathrm{ml}, 100 \mu \mathrm{g} / \mathrm{ml})$ & Sasaki et al. (2002) \\
\hline & HIV-1 & $\begin{array}{l}\text { Reduces the fluidity of cell membrane, resulting in a } \\
\text { decrease in intercellular fusion, thus inhibiting the } \\
\text { transmission of HIV between cells }\end{array}$ & $\begin{array}{l}\text { Glycyrrhizin }(0.06 \mathrm{mg} / \mathrm{ml}, 0.13 \mathrm{mg} / \mathrm{ml}, 0.25 \mathrm{mg} / \mathrm{ml} \text {, } \\
0.5 \mathrm{mg} / \mathrm{ml}, 1 \mathrm{mg} / \mathrm{ml})\end{array}$ & Harada, (2005) \\
\hline \multirow[t]{2}{*}{ SARS-CoV } & SARS-CoV & $\begin{array}{l}\text { Inhibits virus replication; inhibits the adsorption and } \\
\text { infiltration of viruses }\end{array}$ & $\begin{array}{l}\text { Glycyrrhizin (after virus adsorption, } \mathrm{EC}_{50}=600 \mu \mathrm{g} / \mathrm{ml} \\
\text { during and after virus adsorption, } \mathrm{EC}_{50}=300 \mu \mathrm{g} / \mathrm{ml} \text {; } \\
\text { during virus adsorption, } \mathrm{EC}_{50}=2,400 \mu \mathrm{g} / \mathrm{ml} \text { ) }\end{array}$ & Cinatl et al. (2003) \\
\hline & SARS-CoV-2 & Inhibition of HMGB1 release; inhibition of virus replication & Glycyrrhizin (10 mM, 250 mM, 1,000 $\mu \mathrm{M})$ & Gowda et al. (2021) \\
\hline \multirow[t]{5}{*}{$\begin{array}{l}\text { Animal } \\
\text { viruses }\end{array}$} & IBV & $\begin{array}{l}\text { Direct antiviral effect, inhibit cell infection; decrease } \\
\text { apoptosis of infected cells }\end{array}$ & $\begin{array}{l}\text { Glycyrrhizin diammonium }(0.0225,0.09,0.36 \text {, } \\
1.44 \mathrm{mM})\end{array}$ & Li et al. (2009) \\
\hline & IBDV & $\begin{array}{l}\text { Inhibition of virus replication, direct inactivation of virus, } \\
\text { and inhibition of virus adsorption }\end{array}$ & $\begin{array}{l}\text { Dipotassium glycyrrhizinate }\left(\mathrm{EC}_{50}=663.2 \pm\right. \\
268.4 \mu \mathrm{g} / \mathrm{ml})\end{array}$ & Sun et al. (2013) \\
\hline & PPV & Directly inactivates the virus & Diammonium glycyrrhizinate $(250 \mu \mathrm{g} / \mathrm{ml})$ & Li et al. (2014) \\
\hline & PRRSV & $\begin{array}{l}\text { Directly inactivates PRRSV, inhibits PRRSV invasion and } \\
\text { replication, stimulates cells to produce interferon, and } \\
\text { inhibits PRRSV infection-induced reactive oxygen } \\
\text { species production }\end{array}$ & Glycyrrhizic-acid-based carbon dots $(0.30$ mg/ml) & Tong et al. (2020) \\
\hline & PEDV & $\begin{array}{l}\text { Inhibition of PEDV infection and secretion of } \\
\text { proinflammatory cytokines through the HMGB1/TLR4- } \\
\text { MAPKp38 pathway }\end{array}$ & Glycyrrhizin $(0.1,0.2,0.4,0.8 \mathrm{mM})$ & Gao et al. (2020) \\
\hline
\end{tabular}

innate immune response of antivirus, and inhibit the accumulation of intracellular ROS caused by PRRSV infection (MOI = 1). Glycyrrhizin can also inhibit the entry and replication of porcine epidemic diarrhoea virus (PEDV) but does not affect the assembly and release of the virus (Huan et al., 2017). Inhibition of PEDV infection (MOI = 0.1) and secretion of proinflammatory cytokines occurred mainly through the HMGB1/TLR4-MAPK p38 pathway (Gao et al., 2020).

\section{DISCUSSION}

Glycyrrhizin and its derivative protect against many viruses through their antiviral activity (Table 1). The main mechanisms of action of these compounds include inhibition of virus replication, direct inactivation of viruses, inhibition of the replication and expression of viral genes, increase in cell death, inhibition of inflammation 


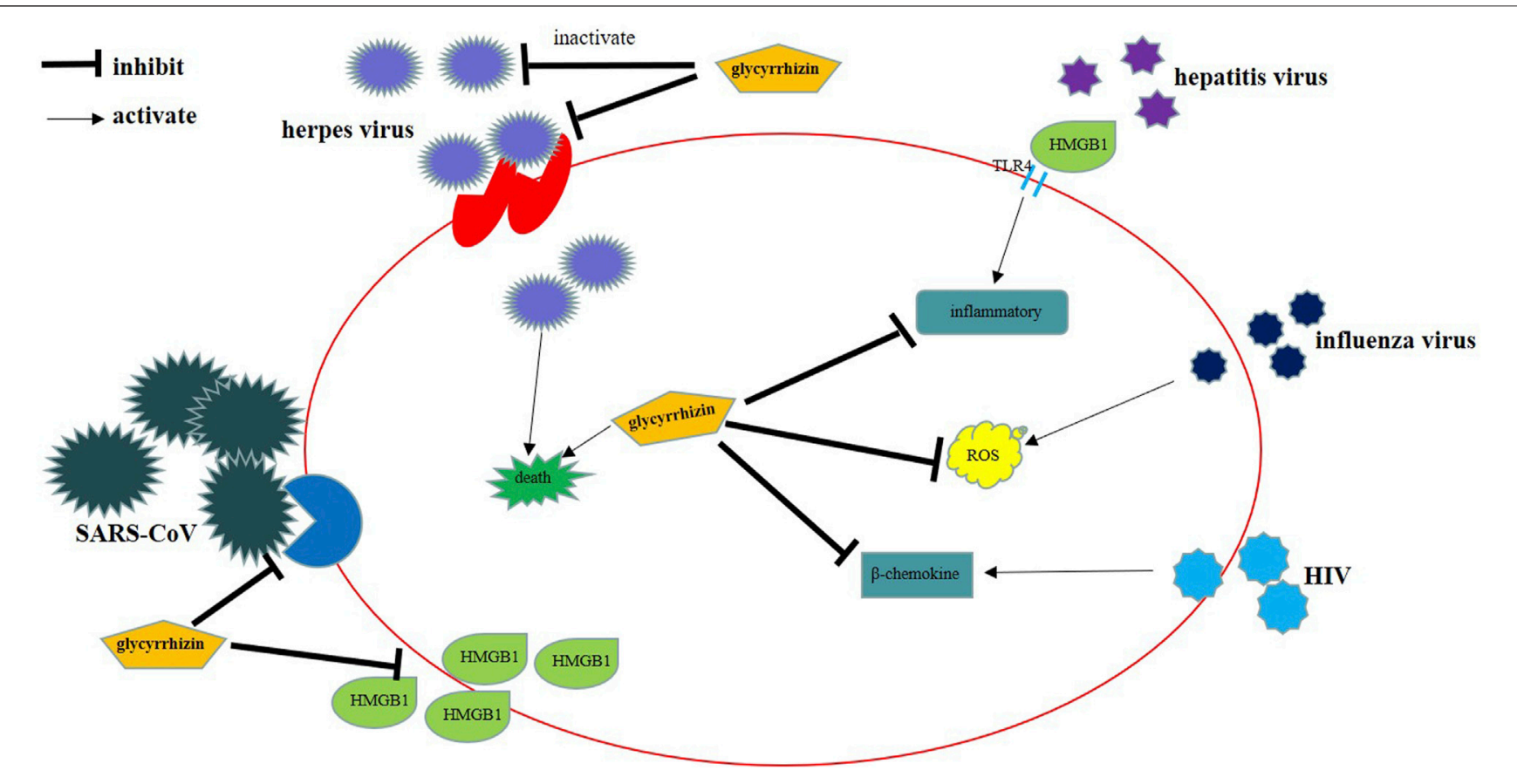

FIGURE 2 | The mechanisms of action of glycyrrhizin against viruses.

mediated by HMGB1/TLR4, inhibition of $\beta$-chemokines, reduction in HMGB1 release, reduction in the fluidity of the cell membrane, reduction in the binding of HMGB1 to DNA to weaken the activity of viruses, and inhibition of the formation of ROS (Figure 2). The mechanisms of action of glycyrrhizin against viruses are complex; however, many mechanisms remain unknown. Therefore, elucidation of the antiviral mechanism of glycyrrhizin may help in developing strategies to enhance its antiviral activity and is a subject worthy of further studies. In our further studies, we aim to focus on exploring the mechanisms through which glycyrrhizin induces direct inactivation of viruses and inflammatory and immune responses.

COVID-19 has become a pandemic. Although vaccines have been approved, they have not been widely used and no specific treatment for COVID-19 is available to date (Al-Kamel and Grundmann, 2021). Glycyrrhizin exerts extensive antiviral effect and obvious inhibitory effects on SARS-CoV; therefore, glycyrrhizin may be an effective drug against COVID-19. Ding et al. provided the clinical data of a critically ill patient with COVID-19 who was cured by a combination of DG and vitamin C (Ding et al., 2020). SARS$\mathrm{CoV}-2$ has been shown to enter cells through angiotensin-converting enzyme 2 (ACE2) receptors (Letko et al., 2020; Wan et al., 2020; Xu et al., 2020). Therefore, targeting ACE2 could be a promising strategy to prevent SARS-CoV-2 infection. Glycyrrhizin was recently shown to have the potential to bind to ACE2 (Zhou and Huang, 2020). All these findings suggest that the use of glycyrrhizin could be promising in COVID-19 treatment.

Structural modification of natural products is one of the approaches to discover novel drugs. Through structural modification, the potency and solubility of natural products can be increased, pharmacokinetic properties such as absorption and distribution can be improved, and side effects can be eliminated or reduced (Chen et al., 2015a). Many artificially modified natural product derivatives, such as artemisinin (antimalaria) and paclitaxel (anticancer), have been successfully used in clinics (Yao et al., 2017). Some glycyrrhizin derivatives have demonstrated stronger antiviral activity than glycyrrhizin, although with higher cytotoxicity (Hoever et al., 2005; Baltina et al., 2019; El-Senduny et al., 2019). Therefore, structural modification of glycyrrhizin in the future could be valuable for identifying glycyrrhizin derivatives with the highest antiviral activity and least cytotoxicity. The use of a combination of two or more drugs is another approach to improve efficacy and reduce side effects of drugs. Since the approval of the first batch of combination drugs by FDA in the 1940s, combination drugs have become invaluable for clinical application (Das et al., 2019). The combinations of glycyrrhizin with entecavir, lamivudine, and other drugs have been reported to yield superior clinical outcomes (Ide et al., 2005; Chen et al., 2020; Minsart et al., 2020; Yu et al., 2020); therefore the potential of combining glycyrrhizin with other drugs must be explored in future studies.

The United States Food and Drug Administration, Council of Europe, and Joint FAO/WHO Expert Committee on Food Additives have allowed the use of liquorice extract and glycyrrhizin in food (Pastorino et al., 2018). Although liquorice is believed to be a healthy natural herb without any serious adverse effects (Kwon et al., 2020), it should be used with caution, particularly in patients with hypertension, considering its side effects. Side effects reported in literature include hypokalaemia (Sontia et al., 2008; Flores-Robles et al., 2013), hypertension (Smedegaard and Svart, 2019), hypertensive encephalopathy (Russo et al., 2000), rhabdomyolysis (Alaygut et al., 2017), and cardiac arrest (Attou et al., 2020). A good correlation has been observed between the content of glycyrrhizin and the incidence of side effects, which indicates that the content of 
glycyrrhizin is a suitable index to avoid adverse reactions (Nose et al., 2017). However, the upper safe limit of glycyrrhizin remains to be determined. The European Union recommends an upper limit of $100 \mathrm{mg}$ of glycyrrhizin per day (Murphy et al., 2009). Based on in vivo results and clinical evidence, Isbrucker et al. recommended that the acceptable daily intake of glycyrrhizin is $0.015-0.229 \mathrm{mg} / \mathrm{kg}$ body weight/day (Isbrucker and Burdock, 2006). This range is consistent with the $0.2 \mathrm{mg} / \mathrm{kg}$ body weight/day proposed by van Gelderen et al. (2000). Considering the well-known biological functions and side effects of glycyrrhizin, the use of an appropriately controlled dosage of liquorice can lead to its health benefits outweigh its side effects.

\section{AUTHOR CONTRIBUTIONS}

All the authors listed have made a substantial, direct, and intellectual contribution to the work and approved it for publication.

\section{REFERENCES}

Al-Kamel, H., and Grundmann, O. (2021). Glycyrrhizin as a Potential Treatment for the Novel Coronavirus (COVID-19). Mini. Rev. Med. Chem. 21, 1-5. doi:10.2174/1389557521666210210160237

Alaygut, D., Bayram, M. T., Kasap, B., Soylu, A., Türkmen, M., and Kavukcu, S. (2017). Rhabdomyolysis with Different Etiologies in Childhood. World J. Clin. Pediatr. 6 (4), 161-168. doi:10.5409/wjcp.v6.i4.161

Alkhatib, G., Combadiere, C., Broder, C. C., Feng, Y., Kennedy, P. E., Murphy, P. M., et al. (1996). CC CKR5: A RANTES, MIP-1, MIP-1 Receptor as a Fusion Cofactor for Macrophage-Tropic HIV-1. Science 272 (5270), 1955-1958. doi:10.1126/science.272.5270.1955

Ashfaq, U. A., Masoud, M. S., Nawaz, Z., and Riazuddin, S. (2011). Glycyrrhizin as Antiviral Agent against Hepatitis C Virus. J. Transl Med. 9, 112. doi:10.1186/ 1479-5876-9-112

Attou, R., Redant, S., Honore, P. M., Preseau, T., Hantson, P., and De Bels, D. (2020). Liquorice Intoxication Can Lead to Cardiac Arrest!. Case Rep. Emerg. Med. 2020, 1-3. doi:10.1155/2020/3727682

Bailly, C., and Vergoten, G. (2020). Glycyrrhizin: An Alternative Drug for the Treatment of COVID-19 Infection and the Associated Respiratory Syndrome?. Pharmacol. Ther. 214, 107618. doi:10.1016/j.pharmthera.2020.107618

Baltina, L. A., Tasi, Y.-T., Huang, S.-H., Lai, H.-C., Baltina, L. A., Petrova, S. F., et al. (2019). Glycyrrhizic Acid Derivatives as Dengue Virus Inhibitors. Bioorg. Med. Chem. Lett. 29 (20), 126645. doi:10.1016/j.bmcl.2019.126645

Bentz, G. L., Lowrey, A. J., Horne, D. C., Nguyen, V., Satterfield, A. R., Ross, T. D., et al. (2019). Using Glycyrrhizic Acid to Target Sumoylation Processes during Epstein-Barr Virus Latency. PLoS One 14 (5), e0217578. doi:10.1371/ journal.pone.0217578

Bradley, H., Markowitz, L. E., Gibson, T., and McQuillan, G. M. (2014). Seroprevalence of Herpes Simplex Virus Types 1 and 2--United States, 1999-2010. J. Infect. Dis. 209 (3), 325-333. doi:10.1093/infdis/jit458

Chayavichitsilp, P., Buckwalter, J. V., Krakowski, A. C., and Friedlander, S. F. (2009). Herpes Simplex. Pediatr. Rev. 30 (4), 119-130. doi:10.1542/pir.30-4-119

Chen, F., Chan, K. H., Jiang, Y., Kao, R. Y. T., Lu, H. T., Fan, K. W., et al. (2004). In Vitro susceptibility of 10 Clinical Isolates of SARS Coronavirus to Selected Antiviral Compounds. J. Clin. Virol. 31 (1), 69-75. doi:10.1016/ j.jcv.2004.03.003

Chen, J., Li, W., Yao, H., and Xu, J. (2015a). Insights into Drug Discovery from Natural Products through Structural Modification. Fitoterapia 103, 231-241. doi:10.1016/j.fitote.2015.04.012

Chen, L., Hu, C., Hood, M., Zhang, X., Zhang, L., Kan, J., et al. (2020). A Novel Combination of Vitamin C, Curcumin and Glycyrrhizic Acid Potentially Regulates Immune and Inflammatory Response Associated with Coronavirus Infections: A Perspective from System Biology Analysis. Nutrients 12 (4), 1193. doi:10.3390/nu12041193

\section{FUNDING}

This research was funded by the National Natural Science Foundation of China (31902253), the Natural Science Foundation of Jiangsu Province (BK20180921), the individual technology research and development of modern agricultural industry of Jiangsu Province (CX(19)3024), the China Postdoctoral Science Foundation (2018M632399), the Priority Academic Program Development of Jiangsu Higher Education Institutions (PAPD), and the earmarked fund for Jiangsu Agricultural Industry Technology System.

\section{ACKNOWLEDGMENTS}

We thank Xiang Mao for editing the English text of a draft of this manuscript.

Chen, Q., Chen, H., Wang, W., Liu, J., Liu, W., Ni, P., et al. (2017). Glycyrrhetic Acid, but Not Glycyrrhizic Acid, Strengthened Entecavir Activity by Promoting its Subcellular Distribution in the Liver via Efflux Inhibition. Eur. J. Pharm. Sci. 106, 313-327. doi:10.1016/j.ejps.2017.06.015

Chen, X. X., Zhou, H. X., Qi, W. B., Ning, Z. Y., Ma, Y. J., Li, Y. L., et al. (2015b). Antiviral Effects of the Combination of Glycyrrhizin and Ribavirin against Influenza A H1N1 Virus Infection In Vivo. Yao Xue Xue Bao 50 (8), 966-972.

Chrzanowski, J., Chrzanowska, A., and Graboń, W. (2021). Glycyrrhizin: An Old Weapon against a Novel Coronavirus. Phytotherapy Res. 35 (2), 629-636. doi:10.1002/ptr.6852

Cinatl, J., Morgenstern, B., Bauer, G., Chandra, P., Rabenau, H., and Doerr, H. (2003). Glycyrrhizin, an Active Component of Liquorice Roots, and Replication of SARS-Associated Coronavirus. The Lancet 361 (9374), 2045-2046. doi:10.1016/s0140-6736(03)13615-x

Cocchi, F., DeVico, A. L., Garzino-Demo, A., Cara, A., Gallo, R. C., and Lusso, P. (1996). The V3 Domain of the HIV-1 Gp120 Envelope Glycoprotein Is Critical for Chemokine-Mediated Blockade of Infection. Nat. Med. 2 (11), 1244-1247. doi:10.1038/nm1196-1244

Coronaviridae Study Group of the International Committee on Taxonomy of V (2020). The Species Severe Acute Respiratory Syndrome-Related Coronavirus: Classifying 2019-nCoV and Naming it SARS-CoV-2. Nat. Microbiol. 5 (4), 536-544. doi:10.1038/s41564-020-0695-Z

Curreli, F., Friedman-Kien, A. E., and Flore, O. (2005). Glycyrrhizic Acid Alters Kaposi Sarcoma-Associated Herpesvirus Latency, Triggering P53-Mediated Apoptosis in Transformed B Lymphocytes. J. Clin. Invest. 115 (3), 642-652. doi:10.1172/JCI2333410.1172/jci200523334

Dargan, D. J., and Subak-Sharpe, J. H. (1986). The Antiviral Activity against Herpes Simplex Virus of the Triterpenoid Compounds Carbenoxolone Sodium and Cicloxolone Sodium. J. Antimicrob. Chemother. 18 (Suppl. B), 185-200. doi:10.1093/jac/18.supplement_b.185

Das, P., Delost, M. D., Qureshi, M. H., Smith, D. T., and Njardarson, J. T. (2019). A Survey of the Structures of US FDA Approved Combination Drugs. J. Med. Chem. 62 (9), 4265-4311. doi:10.1021/acs.jmedchem.8b01610

Deng, Q.-P., Wang, M.-J., Zeng, X., Chen, G. G., and Huang, R.-Y. (2017). Effects of Glycyrrhizin in a Mouse Model of Lung Adenocarcinoma. Cell Physiol. Biochem. 41 (4), 1383-1392. doi:10.1159/000467897

Ding, H., Deng, W., Ding, L., Ye, X., Yin, S., and Huang, W. (2020). Glycyrrhetinic Acid and its Derivatives as Potential Alternative Medicine to Relieve Symptoms in Nonhospitalized COVID-19 Patients. J. Med. Virol. 92, 2200-2204. doi:10.1002/jmv.26064

Dragic, T., Litwin, V., Allaway, G. P., Martin, S. R., Huang, Y., Nagashima, K. A., et al. (1996). HIV-1 Entry into CD4+ Cells Is Mediated by the Chemokine Receptor CC-CKR-5. Nature 381 (6584), 667-673. doi:10.1038/381667a0

Drugs B.I. (2006). "Licorice," in Drugs and Lactation Database (LactMed) (Bethesda, MD: National Library of Medicine). 
Duan, E., Wang, D., Fang, L., Ma, J., Luo, J., Chen, H., et al. (2015). Suppression of Porcine Reproductive and Respiratory Syndrome Virus Proliferation by Glycyrrhizin. Antiviral Res. 120, 122-125. doi:10.1016/j.antiviral.2015.06.001

El-Senduny, F. F., Zidane, M. M., Youssef, M. M., and Badria, F. A. (2019). An Approach to Treatment of Liver Cancer by Novel Glycyrrhizin Derivative. Acamc 19 (15), 1863-1873. doi:10.2174/1871520619666190411114718

Feng, Y., Broder, C. C., Kennedy, P. E., and Berger, E. A. (2011). Pillars Article: HIV-1 Entry Cofactor: Functional cDNA Cloning of a Seven-Transmembrane, G Protein-Coupled Receptor. Science. 1996. 272: 872-877. J. Immunol. 186 (11), 6076-6081.

Flores Robles, B. J., Hurtarte Sandoval, A. R., Penate Dardon, J. D., and Alonso Blas, C. (2013). Lethal Liquorice Lollies (Liquorice Abuse Causing Pseudohyperaldosteronism). Case Rep. 2013, bcr2013201007. doi:10.1136/ bcr-2013-201007

Fujisawa, K. (1991). Interferon Therapy in Hepatitis C Virus (HCV) Induced Chronic Hepatitis: Clinical Significance of Pretreatment with Glycyrhizine. Trop. Gastroenterol. 12 (4), 176-179.

Gao, R., Zhang, Y., Kang, Y., Xu, W., Jiang, L., Guo, T., et al. (2020). Glycyrrhizin Inhibits PEDV Infection and Proinflammatory Cytokine Secretion via the HMGB1/TLR4-MAPK P38 Pathway. Int. J. Mol. Sci. 21 (8), 2961. doi:10.3390/ijms21082961

Gowda, P., Patrick, S., Joshi, S. D., Kumawat, R. K., and Sen, E. (2021). Glycyrrhizin Prevents SARS-CoV-2 S1 and Orf3a Induced High Mobility Group Box 1 (HMGB1) Release and Inhibits Viral Replication. Cytokine 142, 155496. doi:10.1016/j.cyto.2021.155496

Harada, S. (2005). The Broad Anti-viral Agent Glycyrrhizin Directly Modulates the Fluidity of Plasma Membrane and HIV-1 Envelope. Biochem. J. 392 (Pt 1), 191-199. doi:10.1042/BJ20051069

Hattori, T., Ikematsu, S., Koito, A., Matsushita, S., Maeda, Y., Hada, M., et al. (1989). Preliminary Evidence for Inhibitory Effect of Glycyrrhizin on HIV Replication in Patients with AIDS. Antivir. Res. 11 (5-6), 255-261. doi:10.1016/ 0166-3542(89)90035-1

Hidaka, I., Hino, K., Korenaga, M., Gondo, T., Nishina, S., Ando, M., et al. (2007). Stronger Neo-Minophagen C?, a Glycyrrhizin-Containing Preparation, Protects Liver against Carbon Tetrachloride-Induced Oxidative Stress in Transgenic Mice Expressing the Hepatitis C Virus Polyprotein. Liver Int. 27 (6), 845-853. doi:10.1111/j.1478-3231.2007.01492.x

Hirabayashi, K., Iwata, S., Matsumoto, H., Mori, T., Shibata, S., Baba, M., et al. (1991). Antiviral Activities of Glycyrrhizin and its Modified Compounds against Human Immunodeficiency Virus Type 1(HIV-1) and Herpes Simplex Virus Type 1(HSV-1) In Vitro. Chem. Pharm. Bull. 39 (1), 112-115. doi:10.1248/cpb.39.112

Hoever, G., Baltina, L., Michaelis, M., Kondratenko, R., Baltina, L., Tolstikov, G. A., et al. (2005). Antiviral Activity of Glycyrrhizic Acid Derivatives against SARS-Coronavirus. J. Med. Chem. 48 (4), 1256-1259. doi:10.1021/jm0493008

Huan, C.-c., Wang, H.-x., Sheng, X.-x., Wang, R., Wang, X., and Mao, X. (2017). Glycyrrhizin Inhibits Porcine Epidemic Diarrhea Virus Infection and Attenuates the Proinflammatory Responses by Inhibition of High Mobility Group Box-1 Protein. Arch. Virol. 162 (6), 1467-1476. doi:10.1007/s00705-017$3259-7$

Huan, C., Chen, C., Xu, W., Guo, T., Pan, H., and Gao, S. (2020). Study on Antiviral Activities of Glycyrrhizin. Int. J. Biomed. Eng. Clin. Sci. 6 (4), 68-70. doi:10.11648/j.ijbecs.20200604.11

Huang, W., Chen, X., Li, Q., Li, P., Zhao, G., Xu, M., et al. (2012). Inhibition of Intercellular Adhesion in Herpex Simplex Virus Infection by Glycyrrhizin. Cell Biochem Biophys. 62 (1), 137-140. doi:10.1007/s12013-011-9271-8

Ide, T., Kumashiro, R., Kuwahara, R., Koga, H., Koga, Y., Hino, T., et al. (2005). Clinical Course of Patients with Chronic Hepatitis B with Viral Breakthrough during Long-Term Lamivudine Treatment. J. Gastroenterol. 40 (6), 625-630. doi:10.1007/s00535-005-1597-9

Ikeda, T., Yokomizo, K., Okawa, M., Tsuchihashi, R., Kinjo, J., Nohara, T., et al. (2005). Anti-herpes Virus Type 1 Activity of Oleanane-type Triterpenoids. Biol. Pharm. Bull. 28 (9), 1779-1781. doi:10.1248/bpb.28.1779

Isbrucker, R. A., and Burdock, G. A. (2006). Risk and Safety Assessment on the Consumption of Licorice Root (Glycyrrhiza sp.), its Extract and Powder as a Food Ingredient, with Emphasis on the Pharmacology and Toxicology of Glycyrrhizin. Regul. Toxicol. Pharmacol. 46 (3), 167-192. doi:10.1016/ j.yrtph.2006.06.002
Ito, M., Nakashima, H., Baba, M., Pauwels, R., De Clercq, E., Shigeta, S., et al. (1987). Inhibitory Effect of Glycyrrhizin on the In Vitro Infectivity and Cytopathic Activity of the Human Immunodeficiency Virus [HIV (HTLVIII/LAV)]. Antiviral Res. 7 (3), 127-137. doi:10.1016/0166-3542(87)90001-5

Ito, M., Sato, A., Hirabayashi, K., Tanabe, F., Shigeta, S., Baba, M., et al. (1988). Mechanism of Inhibitory Effect of Glycyrrhizin on Replication of Human Immunodeficiency Virus (HIV). Antiviral Res. 10 (6), 289-298. doi:10.1016/ 0166-3542(88)90047-2

Kang, H., and Lieberman, P. M. (2011). Mechanism of Glycyrrhizic Acid Inhibition of Kaposi's Sarcoma-Associated Herpesvirus: Disruption of CTCF-CohesinMediated RNA Polymerase II Pausing and Sister Chromatid Cohesion. J. Virol. 85 (21), 11159-11169. doi:10.1128/JVI.00720-11

Korenaga, M., Hidaka, I., Nishina, S., Sakai, A., Shinozaki, A., Gondo, T., et al. (2011). A Glycyrrhizin-Containing Preparation Reduces Hepatic Steatosis Induced by Hepatitis C Virus Protein and Iron in Mice. Liver Int. 31 (4), 552-560. doi:10.1111/j.1478-3231.2011.02469.x

Kwon, Y.-J., Son, D.-H., Chung, T.-H., and Lee, Y.-J. (2020). A Review of the Pharmacological Efficacy and Safety of Licorice Root from Corroborative Clinical Trial Findings. J. Med. Food 23 (1), 12-20. doi:10.1089/jmf.2019.4459

Letko, M., Marzi, A., and Munster, V. (2020). Functional Assessment of Cell Entry and Receptor Usage for SARS-CoV-2 and Other Lineage B Betacoronaviruses. Nat. Microbiol. 5 (4), 562-569. doi:10.1038/s41564-020-0688-y

Li, J., Yin, J., Sui, X., Li, G., and Ren, X. (2009). Comparative Analysis of the Effect of Glycyrrhizin Diammonium and Lithium Chloride on Infectious Bronchitis Virus Infectionin Vitro. Avian Pathol. 38 (3), 215-221. doi:10.1080/ 03079450902912184

Li, P., Zou, H., Ren, Y., Zarlenga, D. S., and Ren, X. (2014). Antiviral Effect of Diammonium Glycyrrhizinate on Cell Infection by Porcine Parvovirus. Curr. Microbiol. 69 (1), 82-87. doi:10.1007/s00284-014-0540-9

Li, Q., Guan, X., Wu, P., Wang, X., Zhou, L., Tong, Y., et al. (2020). Early Transmission Dynamics in Wuhan, China, of Novel Coronavirus-Infected Pneumonia. N. Engl. J. Med. 382 (13), 1199-1207. doi:10.1056/ NEJMoa2001316

Li, X., Sun, R., and Liu, R. (2019). Natural Products in Licorice for the Therapy of Liver Diseases: Progress and Future Opportunities. Pharmacol. Res. 144, 210-226. doi:10.1016/j.phrs.2019.04.025

Lin, J.-C., Cherng, J.-M., Hung, M.-S., Baltina, L. A., Baltina, L., and Kondratenko, R. (2008). Inhibitory Effects of Some Derivatives of Glycyrrhizic Acid against Epstein-Barr Virus Infection: Structure-Activity Relationships. Antiviral Res. 79 (1), 6-11. doi:10.1016/j.antiviral.2008.01.160

Lin, J.-C. (2003). Mechanism of Action of Glycyrrhizic Acid in Inhibition of Epstein-Barr Virus Replication In Vitro. Antiviral Res. 59 (1), 41-47. doi:10.1016/s0166-3542(03)00030-5

Lu, H. Y., Huo, N., Wang, G. F., Li, H. C., Nie, L. G., and Xu, X. Y. (2003). Clinical Observation of Therapeutic Effect of Compound Glycyrrhizin on SARS. China Pharm. (10), 34-36.

Luo, P., Liu, D., and Li, J. (2020). Pharmacological Perspective: Glycyrrhizin May Be an Efficacious Therapeutic Agent for COVID-19. Int. J. Antimicrob. Agents 55 (6), 105995. doi:10.1016/j.ijantimicag.2020.105995

Matsumoto, Y., Matsuura, T., Aoyagi, H., Matsuda, M., Hmwe, S. S., Date, T., et al. (2013). Antiviral Activity of Glycyrrhizin against Hepatitis C Virus In Vitro. PLoS One 8 (7), e68992. doi:10.1371/journal.pone.0068992

Matsuo, K., Takenaka, K., Shimomura, H., Fujii, N., Shinagawa, K., Kiura, K., et al. (2001). Lamivudine and Glycyrrhizin for Treatment of Chemotherapy-Induced Hepatitis B Virus (HBV) Hepatitis in a Chronic HBV Carrier with NonHodgkin Lymphoma. Leuk. Lymphoma 41 (1-2), 191-195. doi:10.3109/ 10428190109057970

Michaelis, M., Geiler, J., Naczk, P., Sithisarn, P., Leutz, A., Doerr, H. W., et al. (2011). Glycyrrhizin Exerts Antioxidative Effects in H5N1 Influenza A VirusInfected Cells and Inhibits Virus Replication and Pro-inflammatory Gene Expression. PLoS One 6 (5), e19705. doi:10.1371/journal.pone.0019705

Michaelis, M., Geiler, J., Naczk, P., Sithisarn, P., Ogbomo, H., Altenbrandt, B., et al. (2010). Glycyrrhizin Inhibits Highly Pathogenic H5N1 Influenza A VirusInduced Pro-inflammatory Cytokine and Chemokine Expression in Human Macrophages. Med. Microbiol. Immunol. 199 (4), 291-297. doi:10.1007/s00430010-0155-0

Minsart, C., Rorive, S., Lemmers, A., Quertinmont, E., and Gustot, T. (2020). $\mathrm{N}$-acetylcysteine and Glycyrrhizin Combination: Benefit Outcome in a Murine 
Model of Acetaminophen-Induced Liver Failure. World J. Hepatol. 12 (9), 596-618. doi:10.4254/wjh.v12.i9.596

Moisy, D., Avilov, S. V., Jacob, Y., Laoide, B. M., Ge, X., Baudin, F., et al. (2012). HMGB1 Protein Binds to Influenza Virus Nucleoprotein and Promotes Viral Replication. J. Virol. 86 (17), 9122-9133. doi:10.1128/JVI.00789-12

Mori, K., Sakai, H., Suzuki, S., Sugai, K., Akutsu, Y., Ishikawa, M., et al. (1989). Effects of Glycyrrhizin (SNMC: Stronger Neo-Minophagen C) in Hemophilia Patients with HIV Infection. Tohoku J. Exp. Med. 158 (1), 25-35. doi:10.1620/ tjem. 158.25

Murck, H. (2020). Symptomatic Protective Action of Glycyrrhizin (Licorice) in COVID-19 Infection?. Front. Immunol. 11, 1239. doi:10.3389/ fimmu.2020.01239

Murphy, S. C., Agger, S., and Rainey, P. M. (2009). Too Much of a Good Thing: a Woman with Hypertension and Hypokalemia. Clin. Chem. 55 (12), 2093-2096. doi:10.1373/clinchem.2009.127506

Nose, M., Tada, M., Kojima, R., Nagata, K., Hisaka, S., Masada, S., et al. (2017). Comparison of Glycyrrhizin Content in 25 Major Kinds of Kampo Extracts Containing Glycyrrhizae Radix Used Clinically in Japan. J. Nat. Med. 71 (4), 711-722. doi:10.1007/s11418-017-1101-x

Okda, F. A., Yassein, S., Ahmed, A. R., Soufy, H., and Nasr, S. M. (2013). Some Haematological and Biochemical Investigations on Duck Virus Hepatitis Following Administration of Glycyrrhizin. ISRN Pharmacol. 2013, 1-10. doi:10.1155/2013/849412

Okonko, I., and Cookey, T. (2015). Seropositivity and Determinants of Immunoglobulin-G (IgG) Antibodies against Herpes Simplex Virus (HSV) Types -1 and -2 in Pregnant Women in Port Harcourt, Nigeria. Afr. Health. Sci. 15 (3), 737-747. doi:10.4314/ahs.v15i3.6

Pastorino, G., Cornara, L., Soares, S., Rodrigues, F., and Oliveira, M. B. P. P. (2018). Liquorice (Glycyrrhiza Glabra ): A Phytochemical and Pharmacological Review. Phytotherapy Res. 32 (12), 2323-2339. doi:10.1002/ptr.6178

Paudel, Y. N., Angelopoulou, E., Semple, B., Piperi, C., Othman, I., and Shaikh, M. F. (2020). Potential Neuroprotective Effect of the HMGB1 Inhibitor Glycyrrhizin in Neurological Disorders. ACS Chem. Neurosci. 11 (4), 485-500. doi:10.1021/acschemneuro.9b00640

Petramfar, P., Hajari, F., Yousefi, G., Azadi, S., and Hamedi, A. (2020). Efficacy of Oral Administration of Licorice as an Adjunct Therapy on Improving the Symptoms of Patients with Parkinson's Disease, A Randomized Double Blinded Clinical Trial. J. Ethnopharmacology 247, 112226. doi:10.1016/j.jep.2019.112226

Pompei, R., Paghi, L., Ingianni, A., and Uccheddu, P. (1983). Glycyrrhizic Acid Inhibits Influenza Virus Growth in Embryonated Eggs. Microbiologica 6 (3), 247-250.

Pompei, R., Flore, O., Marccialis, M. A., Pani, A., and Loddo, B. (1979). Glycyrrhizic Acid Inhibits Virus Growth and Inactivates Virus Particles. Nature 281 (5733), 689-690. doi:10.1038/281689a0

$\mathrm{Pu}$, J. Y., He, L., Wu, S. Y., Zhang, P., and Huang, X. (2013). Anti-virus Research of Triterpenoids in Licorice. Bing Du Xue Bao 29 (6), 673-679.

Reward, E. E., Muo, S. O., Orabueze, I. N. A., and Ike, A. C. (2019). Seroprevalence of Herpes Simplex Virus Types 1 and 2 in Nigeria: a Systematic Review and Meta-Analyses. Pathog. Glob. Health 113 (5), 229-237. doi:10.1080/ 20477724.2019.1678938

Romero, M. R., Efferth, T., Serrano, M. A., Castaño, B., Macias, R. I. R., Briz, O., et al. (2005). Effect of Artemisinin/artesunate as Inhibitors of Hepatitis B Virus Production in an "In Vitro" Replicative System. Antiviral Res. 68 (2), 75-83. doi:10.1016/j.antiviral.2005.07.005

Russo, S., Mastropasqua, M., Mosetti, M. A., Persegani, C., and Paggi, A. (2000). Low Doses of Liquorice Can Induce Hypertension Encephalopathy. Am. J. Nephrol. 20 (2), 145-148. doi:10.1159/000013572

Sakai-Sugino, K., Uematsu, J., Kamada, M., Taniguchi, H., Suzuki, S., Yoshimi, Y., et al. (2017). Glycyrrhizin Inhibits Human Parainfluenza Virus Type 2 Replication by the Inhibition of Genome RNA, mRNA and Protein Syntheses. Drug Discov. Ther. 11 (5), 246-252. doi:10.5582/ddt.2017.01048

Sasaki, H., Takei, M., Kobayashi, M., Pollard, R. B., and Suzuki, F. (2002). Effect of Glycyrrhizin, an Active Component of Licorice Roots, on HIV Replication in Cultures of Peripheral Blood Mononuclear Cells from HIV-Seropositive Patients. Pathobiology 70 (4), 229-236. doi:10.1159/000069334

Sato, H., Goto, W., Yamamura, J., Kurokawa, M., Kageyama, S., Takahara, T., et al. (1996). Therapeutic Basis of Glycyrrhizin on Chronic Hepatitis B. Antivir. Res. 30 (2-3), 171-177. doi:10.1016/0166-3542(96)00942-4
Sekizawa, T., Yanagi, K., and Itoyama, Y. (2001). Glycyrrhizin Increases Survival of Mice with Herpes Simplex Encephalitis. Acta Virol. 45 (1), 51-54. doi:10.1007/ s00122-004-1752-3

Shi, X., Yu, L., Zhang, Y., Liu, Z., Zhang, H., Zhang, Y., et al. (2020). Glycyrrhetinic Acid Alleviates Hepatic Inflammation Injury in Viral Hepatitis Disease via a HMGB1-TLR4 Signaling Pathway. Int. Immunopharmacol. 84, 106578. doi:10.1016/j.intimp.2020.106578

Sinha, S. K., Prasad, S. K., Islam, M. A., Chaudhary, S. K., Singh, S., and Shakya, A. (2021). Potential Leads from Liquorice Against SARS-CoV-2 Main Protease Using Molecular Docking Simulation Studies. Comb. Chem. High Throughput. Screen 24 (4), 591-597. doi:10.2174/1386207323999200817103148

Smedegaard, S. B., and Svart, M. V. (2019). Licorice Induced Pseudohyperaldosteronism, Severe Hypertension, and Long QT. Endocrinol. Diabetes Metab. Case Rep. 2019, 1-4. doi:10.1530/EDM-19-0109

Smirnov, V. S., Zarubaev, V. V., Anfimov, P. M., and Shtro, A. A. (2012). Effect of a Combination of Glutamyl-Tryptophan and Glycyrrhizic Acid on the Course of Acute Infection Caused by Influenza (H3H2) Virus in Mice. Vopr Virusol 57 (3), 23-27.

Sontia, B., Mooney, J., Gaudet, L., and Touyz, R. M. (2008). Pseudohyperaldosteronism, Liquorice, and Hypertension. J. Clin. Hypertens. 10 (2), 153-157. doi:10.1111/j.1751-7176.2008.07470.x

Soufy, H., Yassein, S., Ahmed, A., Khodier, M., Kutkat, M., Nasr, S., et al. (2012). Antiviral and Immune Stimulant Activities of Glycyrrhizin against Duck Hepatitis Virus. Afr. J. Trad. Compl. Alt. Med. 9 (3), 389-395. doi:10.4314/ ajtcam.v9i3.14

Sun, X., Zeng, H., Wang, Q., Yu, Q., Wu, J., Feng, Y., et al. (2018). Glycyrrhizin Ameliorates Inflammatory Pain by Inhibiting Microglial Activation-Mediated Inflammatory Response via Blockage of the HMGB1-TLR4-NF-kB Pathway. Exp. Cel Res. 369 (1), 112-119. doi:10.1016/j.yexcr.2018.05.012

Sun, Y., Song, M., Niu, L., Bai, X., Sun, N., Zhao, X., et al. (2013). Antiviral Effects of the Constituents Derived from Chinese Herb Medicines on Infectious Bursal Disease Virus. Pharm. Biol. 51 (9), 1137-1143. doi:10.3109/13880209.2013.781197

Takahara, T., Watanabe, A., and Shiraki, K. (1994). Effects of Glycyrrhizin on Hepatitis B Surface Antigen: a Biochemical and Morphological Study. J. Hepatol. 21 (4), 601-609. doi:10.1016/s0168-8278(94)80108-8

Takei, M., Kobayashi, M., Li, X.-D., Pollard, R. B., and Suzuki, F. (2005). Glycyrrhizin Inhibits R5 HIV Replication in Peripheral Blood Monocytes Treated with 1-methyladenosine. Pathobiology 72 (3), 117-123. doi:10.1159/ 000084114

Tandon, A., Tandon, B. N., and Bhujwala, R. A. (2001). Treatment of Subacute Hepatitis with Lamivudine and Intravenous Glycyrrhizin: a Pilot Study. Hepatol. Res. 20 (1), 1-8. doi:10.1016/s1386-6346(00)00123-6

Tarao, K. (2001). Prevention of Development of Hepatocellular Carcinoma from HCV-Associated Liver Cirrhosis by Multi-Agents Therapy Including StrongerNeo-Minophagen C. Nihon Rinsho 59 Suppl 6 (Suppl. 6), 769-773.

Tong, T., Hu, H., Zhou, J., Deng, S., Zhang, X., Tang, W., et al. (2020). GlycyrrhizicAcid-Based Carbon Dots with High Antiviral Activity by Multisite Inhibition Mechanisms. Small 16 (13), 1906206. doi:10.1002/smll.201906206

van de Sand, L., Bormann, M., Alt, M., Schipper, L., Heilingloh, C. S., Steinmann, E., et al. (2021). Glycyrrhizin Effectively Inhibits SARS-CoV-2 Replication by Inhibiting the Viral Main Protease. Viruses 13 (4), 609. doi:10.3390/v13040609

van Gelderen, C. E. M., Bijlsma, J. A., van Dokkum, W., and Savelkoull, T. J. F. (2000). Glycyrrhizic Acid: the Assessment of a No Effect Level. Hum. Exp. Toxicol. 19 (8), 434-439. doi:10.1191/096032700682694251

Wan, Y., Shang, J., Graham, R., Baric, R. S., and Li, F. (2020). Receptor Recognition by the Novel Coronavirus from Wuhan: an Analysis Based on Decade-Long Structural Studies of SARS Coronavirus. J. Virol. 94 (7), e00127-20. doi:10.1128/JVI.00127-20

Wang, D., Hu, B., Hu, C., Zhu, F., Liu, X., Zhang, J., et al. (2020). Clinical Characteristics of 138 Hospitalized Patients with 2019 Novel Coronavirus-Infected Pneumonia in Wuhan, China. JAMA 323, 1061. doi:10.1001/jama.2020.1585

Wang, Z.-W., Sun, N., Wu, C.-H., Jiang, J.-B., Bai, Y.-S., and Li, H.-Q. (2013). In Vitro antiviral Activity and Underlying Molecular Mechanisms of Dipotassium Glycyrrhetate against Porcine Reproductive and Respiratory Syndrome Virus. Antivir. Ther. 18 (8), 997-1004. doi:10.3851/IMP2662

Wolkerstorfer, A., Kurz, H., Bachhofner, N., and Szolar, O. H. J. (2009). Glycyrrhizin Inhibits Influenza A Virus Uptake into the Cell. Antiviral Res. 83 (2), 171-178. doi:10.1016/j.antiviral.2009.04.012 
Wu, C. H., Xu, X. Y., Lu, H. Y., ling, X. H., Hou, F. Q., Yu, Y. Y., et al. (2004). Analysis of the Chest X-ray Manifestations in SARS Patients Treated with Compound Glycyrrhizin. China Pharm. (01), 40-42.

Xie, Y., Ruan, B., Chen, Y., Wu, N., Hu, M., and Zhu, B. (2011). Kaposi's SarcomaAssociated Herpesvirus Infection in Chinese Patients with Chronic Hepatitis B. J. Med. Virol. 83 (5), 879-883. doi:10.1002/jmv.22001

Xu, X., Chen, P., Wang, J., Feng, J., Zhou, H., Li, X., et al. (2020). Evolution of the Novel Coronavirus from the Ongoing Wuhan Outbreak and Modeling of its Spike Protein for Risk of Human Transmission. Sci. China Life Sci. 63 (3), 457-460. doi:10.1007/s11427-020-1637-5

Yan, T., Wang, H., Cao, L., Wang, Q., Takahashi, S., Yagai, T., et al. (2018). Glycyrrhizin Alleviates Nonalcoholic Steatohepatitis via Modulating Bile Acids and MetaInflammation. Drug Metab. Dispos 46 (9), 1310-1319. doi:10.1124/dmd.118.082008

Yang, L., Jiang, Y., Zhang, Z., Hou, J., Tian, S., and Liu, Y. (2020). The Anti-diabetic Activity of Licorice, a Widely Used Chinese Herb. J. Ethnopharmacol. 263, 113216. doi:10.1016/j.jep.2020.113216

Yang, X. W. (2020). Antiviral Effect of Glycyrrhizic Acid. Mod. Chin. Med. 22 (04), 533-541.

Yao, H., Liu, J., Xu, S., Zhu, Z., and Xu, J. (2017). The Structural Modification of Natural Products for Novel Drug Discovery. Expert Opin. Drug Discov. 12 (2), 121-140. doi:10.1080/17460441.2016.1272757

Yao, L., and Sun, T. (2019). Glycyrrhizin Administration Ameliorates Streptococcus Aureus-Induced Acute Lung Injury. Int. Immunopharmacol. 70, 504-511. doi:10.1016/j.intimp.2019.02.046

Yoshida, T., Kobayashi, M., Li, X. D., Pollard, R. B., and Suzuki, F. (2009). Inhibitory Effect of Glycyrrhizin on the Neutrophil-dependent Increase of R5 HIV Replication in Cultures of Macrophages. Immunol. Cel Biol. 87 (7), 554-558. doi:10.1038/icb.2009.40

Yu, N., Li, Y., Ding, Y., and Shi, Y. (2020). Combination Therapy with Acitretin and Glycyrrhizin in Generalized Pustular Psoriasis with Liver Test Abnormalities: A Case Series. Dermatol. Ther. 33 (3), e13318. doi:10.1111/dth.13318

Yu, S., Zhu, Y., Xu, J., Yao, G., Zhang, P., Wang, M., et al. (2021). Glycyrrhizic Acid Exerts Inhibitory Activity against the Spike Protein of SARS-CoV-2. Phytomedicine 85, 153364. doi:10.1016/j.phymed.2020.153364
Zeng, L., Li, S. H., and Lou, Z. C. (1988). Morphological and Histological Studies of Chinese Licorice. Yao Xue Xue Bao 23 (3), 200-208.

Zhang, K.-X., Wang, P.-R., Chen, F., Qian, X.-J., Jia, L., Liu, X.-J., et al. (2020). Synthesis and Anti-HCV Activities of $18 \beta$-Glycyrrhetinic Acid Derivatives and Their In-Silico ADMET Analysis. Curr. Comput. Aided Drug Des. 16, 1-7. doi: $10.2174 / 1573409916666200827104008$

Zhang, Q., and Ye, M. (2009). Chemical Analysis of the Chinese Herbal Medicine Gan-Cao (Licorice). J. Chromatogr. A 1216 (11), 1954-1969. doi:10.1016/ j.chroma.2008.07.072

Zhang, Z., Yang, L., Hou, J., Tian, S., and Liu, Y. (2021). Molecular Mechanisms Underlying the Anticancer Activities of Licorice Flavonoids. J. Ethnopharmacol. 267, 113635. doi:10.1016/j.jep.2020.113635

Zhou, J., and Huang, J. (2020). Current Findings Regarding Natural Components with Potential Anti-2019-nCoV Activity. Front. Cel Dev. Biol. 8, 589. doi:10.3389/fcell.2020.00589

Zhou, P., Yang, X.-L., Wang, X.-G., Hu, B., Zhang, L., Zhang, W., et al. (2020). A Pneumonia Outbreak Associated with a New Coronavirus of Probable Bat Origin. Nature 579 (7798), 270-273. doi:10.1038/s41586020-2012-7

Zhu, N., Zhang, D., Wang, W., Li, X., Yang, B., Song, J., et al. (2020). A Novel Coronavirus from Patients with Pneumonia in China, 2019. N. Engl. J. Med. 382 (8), 727-733. doi:10.1056/NEJMoa2001017

Conflict of Interest: The authors declare that the research was conducted in the absence of any commercial or financial relationships that could be construed as a potential conflict of interest.

Copyright (c) 2021 Huan, Xu, Zhang, Guo, Pan and Gao. This is an open-access article distributed under the terms of the Creative Commons Attribution License (CC $B Y$ ). The use, distribution or reproduction in other forums is permitted, provided the original author(s) and the copyright owner(s) are credited and that the original publication in this journal is cited, in accordance with accepted academic practice. No use, distribution or reproduction is permitted which does not comply with these terms. 